\title{
Traditional Ecological Knowledge for the Deer Conservation in the Form of Folklore
}

\author{
Heksa Biopsi Puji Hastuti* \\ Kantor Bahasa Provinsi Sulawesi Tenggara \\ Kendari, Indonesia \\ *Heksa.bph@gmail.com \\ Early Wulandari Muis \\ BKKBN Perwakilan Provinsi Sulawesi Tenggara \\ Kendari, Indonesia
}

\author{
Indra Rahayu Setiawati, Nisa Nasyra Rezki \\ Balitbang Provinsi Sulawesi Tenggara \\ Kendari, Indonesia \\ rahayu_9289@yahoo.com,nisanasyrarezki@yahoo.com
}

\author{
Hasina Fajrin R \\ Balai Bahasa Provinsi Sulawesi Selatan \\ Makassar, Indonesia
}

\begin{abstract}
The Traditional Society of Moronene in HukaeaLaea, Taman Nasional Rawa Aopa Watumohai area, has its mechanism in performing the ecosystem balance, included the deer conservation. The tribe also has a traditional institution called totongano kadadi that can control animal conservation, and the oral tradition called dulele melaa, a folksong narrating the deer hunting. The study aims to reveal the intertextual relationship between the folksong and the traditional institution. The data is obtained through observation, interviews, and library search techniques. Both folklores are analysed intertextually to explain the web of relationships found in them. The result depicts the intertextual relationship of totongano kadadi and dulele melaa in two domains, subject and role. The subject domain, represented by the terms, the setting of events, and the place's setting, is compatible. Also, the role domain of dulele melaa creation becomes the enforcement of the totongano kadadi role. The totongano kadadi role is weakened, dulele melaa is created based on traditional ecological knowledge of totongano kadadi. The excess of wild hunters outside is necessary legal mechanisms more than merely depending on traditional mechanisms. The necessity of the parts, but the traditional society, is crucial to law enforcement for the wild hunters and normalizing the deer population in the Hukaea-Laea area.
\end{abstract}

Keywords-traditional ecological knowledge, the deer conservation, Moronene, Hukaea-Laea, totongano kadadi, dulele melaa

\section{INTRODUCTION}

Natural balance, an ideal concept of the earth where the living creature inhabits, occurs involving plant, animal, and human beings' synergy. Of three components, through their collective effect, human beings more influence the ecosystem [1]. Naturally, the effort of natural balancing conservation embodies human beings' cultural products like folklore and narratives. The short story's protest is the manifestation of social care to be wise in forest conservation in West Kalimantan [2]. Human beings' exertion in transform the ecosystem balance is often recorded in traditional ecological knowledge called folklore, as identified in Indonesian folklores [3]. Folklore becomes notes and evidence of human beings' effort from time to time. Totongano kadadi, an animal conservationist, is a part of the traditional institution of Moronene in Hukaea-Laea, for example, registered as the agent of ecosystem balance to strive for animal conservation in Moronene traditional area in Hukaea-Laea, South East Sulawesi, Indonesia [4]. Unfortunately, in the other commentary, the human beings' ignorant also appear, at least, part of them towards the natural balance on the Moronene land [5]. Therefore, the study of what has been done collectively and its practice in the field is needed.

Several researchers have discussed natural balance appertaining to folklore resources as traditional ecological knowledge of a tribe group. Even though folklore does not exist in its society in its practice, left symbols of the language used could be the source of knowledge related to the valuable human thought for forest conservation [6,7]. As the dominant agent in the universe, human beings have the most significant effect on the universe's survival. Through folklore's account in South Portugal, it reveals the lousy stigma of gecko impacting animal abuse. Still, through folklore, the gecko's geographical distribution is also mapped that the animal's conservation could be conducted [8].

On the contrary, in Buton, South East Sulawesi, empirically, the primates are known as the animal garden destroyer, by its frequency of appearance in folklore, the human beings provide shelter for them [9]. An interesting concept of thought reveals that objective and motivation could be made reciprocally. For a recent study, the cultural aspect is utilized as the natural conservation tool, virtually biological preservation; natural conservation efforts could also be done for cultural preservation purposes [10-11]. Consequently, it could be stated that the significance of folklore as the cultural product and natural balance could have functioned jointly. 
Text in the intertextual framework is unlimited in a particular genre. Intertextuality provides the reader's horizon to freely associate with a previous reading experience that enables reading text richness [12]. The diversity of meaning referred by textual terms in intertextual study substantially is the web of intertext relation [13]. Totongano kadadi, animal conservationist, found in totongano wonua (Moronene traditional institution in Hukaea-Laea), has been analyzed in several kinds of research, specifically in traditional ecosystem balance roles. In the research intertextuality study between totongano kadadi and Dulele Melaa, the Moronene folksong is investigated.

\section{AIM OF THE STUDY}

Totongano kadadi and dulele melaa are two cultural products of Moronene tribe. Therefore, the study aims to reveal the intertextual relationship between the folksong and traditional institution reveal in order to enforce the deer conservation in the Hukaea-Laea area, Taman Nasional Rawa Aopa Watumohai, and to preserve the ecosystem balance.

\section{METHODS}

The research is carried out in the Moronene Hukaea-Laea tribe's traditional area, Regency of Bombana, Province of South East Sulawesi, Indonesia. The data are cultural products of Moronene tribe included totongano kadadi and dulele melaa. Totongano kadadi data, as a part of traditional institution providing the formal attitude data of Moronene tribes towards their ecosystem, is obtained through the triangulation method, observation, interviews, and library searching. Meanwhile, dulele melaa data is acquired by recording, transcribing, and translating into Indonesian language. The data is analyzed by reading in depth dulele melaa text and choosing the dictions in dulele melaa text that have relation with totongano kadadi roles. The dictions are then matched with the similar concept of the deer conservation using intertextual approach.

\section{RESULTS}

Moronene tribe in Hukaea-Laea is mentioned as the oldest tribe domiciling on South East Sulawesi, Indonesia, and classified as a family of old Malay. Moronene society is agrarian and closed to forest life and river that challenge controlling natural resources use. They live collectively in an area called tobu, consisting of woodland as hunting and opening space for cultivation, small rivers, and glades. Moronene people in Hukaea-Laea have fought for a long time to stay in traditional areas since its function changes into a conservation area entitled Taman Nasional Rawa Aopa Watumohai. The legitimation of performing the life based on its custom and tradition begins in Hukaea-Laea since Regional Regulation of Bombana Regency Number 4 the Year 2015 of Recognition, Conservation, and Empowerment of Moronene Hukaea Laea traditional society. The regulation mentions that indigenous people of Moronene Hukaea Lae are a group of Moronene society hereditary live in the geographical area of
Hukaea Laea. The bound of ancestral origin and the relationship with the environment are deep and robust.

The Moronene tribe establishes the life on the river stream path. The birth of the river civilization is caused by its collective life in a particular area, then building the settlement and caused by ecological factors. The fertility of the land is attracted the Moronene society to start and build the civilization in the place. The potential river encourages society to farm. The river flow is streamed to the fields and distributed with fair. Then, they develop the civilization also along with their scattered life around the river. The adaptive process results in the dynamic combination between the inhabitants' needs and the environment potential.

The natural sources of forest support for Moronene society survive; one is the deer as a food source. The existence of the deer in Hukaea-Laea has been written for a long time. Based on interviews, it is uncovered that the savanna in Hukaea, formerly named Keuwia, in the past, it was used by the kings for spending their leisure time to hunt for the deer. Based on the inhabitant, after the Indonesian independence day about the 2000 s, the deer were still easily found in the area. The local sign that proves it is the inhabitant's custom installs hartshorn as the decoration in their homes. The culinary product is also found called topa, which means deer beef jerky, and the stories convey that the deer usually becomes the present for the family and friends.

In carrying out nature, Moronene traditional society has the structure of the traditional institution, totongano wonua, playing a role in controlling the wise use of forest in the agriculture that the forest remains sustainable [14]. In the totongano wonua structure, the totongano kadadi obliges to protect and preserve various animals by managing society's hunt. Totongano kadadi recognizes the resting place and the shelter of all animals, such as the deer (kinokaa/melaa, babi (wawi), snake (ule), bird (тапи-тапи), and the others, called olobu $e^{\prime} a$ (big forest). The Moronene people have local knowledge of techniques and areas for hunting [15]. Of terms owned by Moronene language, the closeness way of life Moronene people to forest and hunt life are represented. The term tompulampu, for example, refers mainly to the expert group of people for hunting. Also, the terms are mepopori, umanda, and dumahu. Mepopori means giving the boundary of an area using the rope to limit deer hunting's movement space. Umanda is a technique of baiting the prey with similar domesticated animals, usually for buffalo and deer. Besides, dumahu is a hunting technique with the dog's help.

To preserve the animals from being exploited, Moronene traditional society develops the traditional belief system to obey all social members, either native or immigrant. Customary law enforced in the hunting area is the prohibition for hunting in certain seasons. Totongano kadadi could determine the time of animals, especially the female deer, to become pregnant and bear a baby. Usually, the forbidden time occurs from November to January when the mating season and August is delivered. The times mentioned make all the people 
prohibited from going to the forest and hunting the deer. The enforcement of the law is believed that the ancestral spirit would rehabilitate the population of the hunt.

In performing animal conservationist duty, either for protected or domesticated, totongano kadadi always discusses with totongano lombo, the Moronene traditional component in Hukaea-Laea, obliging to decide the farming field area to farm and decide the time to open space and farming time. The coordination primarily is done to avoid harmful things of totongano lombo (farming) duty and totongano kadadi (animal) duty. For example, the coordination function includes arranging the society's domesticated animal to avoid the animals disturbing the plant when farming.

The practice of hunting regulation is supported by customary laws like giving sanctions and fines for anyone disobeying the law. The customary law is applied wholly, either on the native or the immigrant of others' tribe. Customary law existing and applying in the society today is recognized as terampu law. Terampu law is made for a serious offense. It hunts intentionally or unintentionally in the forbidden forest or prohibited times without permitting or notifying Puutobu.

Besides totongano kadadi, Moronene people also encourages the education of natural balance through oral narrative. Dulele is one of the folksongs of Moronene. The song has flexibility in content. Moronene people usually create the dulele poem when the story's events are necessary to convey to the community. The principle of oral narrative as the medium of expressing collective message is reflected in the dulele function. Dulele is transmitted when the parents tell the village story to their children [16,17]. Dulele Melaa stories about the hunting for the deer involving the emotional aspect of the deer. Dulele Melaa is expressed in the fine variety of Moronene language. Of the language used, it implies that people create Dulele Melaa in the past. The following, dulele melaa text in Moronene language and its translation.

Maama dahungku dahungku iteendera

Aarakuu pondoku kokeena i pampaku

Maina pando 'u amonta ina'a ra'u

Kokeena i pampaku dahano mora'a dincu

Takoaku dumahu ipongkokoro'o ke'uu

Pontarimaubura aipontumbu u'aateno

Karonganomorako tereu awaahira

Dameraa asaarunu asaampaehaakoa

Karongano mereae morawaniinaa ana

Tombelialiamo itompesasaraakomo

Luenono kondowo ireno tangkeau

Nakumpoperamomo tinubatubaadahu

Tinubatubadahu inereredomaantoa

Mantoanto merungke dahuntoraroeha

Neneangkokaosi cendaindai Piitinoto sosakiporambahi

Ontoopokaasi daho mondaiinara

Keronganonaanai boticongkenorawa

Ohapada iinara tokiadasi ni’i niirako

Kenahinonaana adie iraarono isongkonopenaano
Nahinamonaana atara kauutora

Adiedanirako iedakinaarama

Nahomoo tondianotontoku adietanduupou

Nahinasigunano ikorupekonaano

Kupompaerakongaeae imowawarakoaha

Morawani i boticongke kanahi tompelialiamo

itompesasaraakomo

Mebintainduwa arinoiniipua

Kudaamontulura ndaukuwaicomiu

Nahinaugunano korupokunaano

Topombarena'ai Moiedikeena

Mearuumusunto aidepopaantento

Measada dumahu adiemepoonuпu

Nahookaiporawani adieupuuno touupadaakano

Damompaerakoi mowawarakooaha

Adieboticongke ontomoo'o nee

Nahinaogunano korupekonaano

Mearuohambata die'ubisaaninto

Dao'opinetako dieupoporino

Poporino kaasi takonomiaanono

Kudapiadako ndauukuaaico

Mearuohambata arapenaanto

Kuukuntangkeno kuwarasino olebo

Daho'o pontotoa dieuporambahi

\section{Translation}

I repeatedly call my dog.

Its name is Itendora.

My son take my spear.

The son asks, "Where is it?"

There, it is closed to my machete.

Father will go hunting.

Father asks his son to cut the wood.

While waiting for his back with the hunt result

With Itendora, the father goes hunting.

Father and Itendora meet the herd of the deer.

Buticongke, a white striped deer, leads the herd of the deer.

Buticongke finds former hunting grounds.

Then it said, "being chased by the dog every morning,

Hastily escape since many herds of the deer have died.'

Buticongke tells all the herds.

That all valleys and mountains have many barriers,

Many enemies

Since there are many attacks,

Started by mepopori, dumahu, to umanda"

Buticongke invites the herd of the deer to evacuate in the safe area,

It said, "Let evacuate in Kondowo area of Tangkeau mountain"

Briefly, Dulele melaa narrates the deer's hunting, including four characters: father, son, Itendora (the hound), and Buticongke (the white striped deer that becomes the leader). Before hunting, the father asks the son to prepare the wood for cooking the deer caught. Father hunts the deer using dumahu 
technique, hunting with the dog help. Father and Itedora see the herd of Buticongke. The watchful Buticongke immediately alerts his herd to run for saving their life. Along the way, Buticongke complains about the more insecure condition since they are chased by the hound every morning. Almost all valleys and mountains have barriers. The valleys and the mountains are used as mepopori, dumahu, and umanda places. Many of his herd die. Buticongke decides to carry the herd from the Kondowo area to Tangkeu mountain.

Buticongke, as the animal, impersonates the human being, and his mood is depicted in dulele melaa. He thinks his herd survival, indirectly it becomes an aspect of ecosystem balance. By accentuating Buticongke restlessness, dulele melaa is intended to touch the listeners' feelings and to them aware of animal rights to live. The animal's utilization as the food source should be done wisely, following the customary law's signs. Buticongke directs his herd to evacuate to the Kondowo area, a forest area in the riverside. It is olobu e'a, a place where the animals could evacuate and save themselves from being hunted. In the totongano kadadi rule, the area becomes the place of animal conservation.

Considering the dulele melaa text, the web of relationship intersects with the compatibility of totongano kadadi laws. Dulele melaa presents the deer's perspective as the fugitive (Buticongke and his herd) more than the hunters' perspective (father, son, and Itendora). The hunters' perspective only informs physical activity, such as the preparation of hunting, cooking the fugitive, and the hunter's events and the fugitive meet. At the same time, the perspective of prey includes physical activity and its inner mood. Through Buticongke complaining, the illumination of a tiring herd of the deer facing many attacks like mepopori, dumahu, and umanda is clearly shown. It means that the dumahu hunting technique makes the herd of Buticongke face more fugitive than Bapak's hunting. The various kinds of fugitive forces them to look for other shelters to evacuate since their living space becomes narrower than before.

Pragmatically, the role of totongano kadadi in forest controlling degrades since wild fugitive ignoring the customary law. The ecosystem balance maintained by traditional ecological knowledge through totongano kadadi becomes disturbed. The illegal hunters come from traditional outer areas intensively hunt in their forest. Other textual web shows that dulele melaa is created to be a reminder as to the base for traditional ecological knowledge of sublime and wise totongano kadadi in utilizing nature. For sustaining the balance and the deer is still preserved, it must be obeyed.

Unfortunately, according to traditional leaders and the inhabitants, the wild hunters who come from traditional outer areas hunt illegally since puutobu and the inhabitants do not know. They get into the forest furtively through an unusual path. It makes traditional sanction, terampu could not be applied. The fugitive also is done massively. It contributes significantly to the decrease of the deer population in the traditional area of Hukaea-Laea. The deer are hardly found to feed in Hukaea-Laea savanna or across the Taman Nasional Rawa Aopa Watumohai road. It appears that the existence of the deer's is endangered.

\section{CONCLUSIONS}

The web of the textual relationship of two domains between traditional ecological knowledge of totongano kadadi and dulele melaa is closed. Firstly, the subject domain is represented by corresponding the term, the setting of events, and the place's setting. Secondly, the role domain referred to totongano kadadi role is weakened that needs reinforcement then dulele melaa is created. Fundamentally, it bases on traditional ecological knowledge of totongano kadadi. The excess of the wild hunters needs a more robust law that merely makes customary law solves it. Mechanism embracing other legal parties is encouraged for legal enforcement to the wild hunters and normalizing the deer population in the HukaeaLaea area.

\section{REFERENCES}

[1] J. Kricher, The Balance of Nature: Ecology's Enduring Myth, New Jersey: PrincetonUniversityPress, 2009.

[2] Musfeptial, “Cerpen 'Agik Idup Agik Ngelaban' Menggugah Kearifan Masyarakat dalam Pelestarian Hutan Kalimantan Barat," Kandai, vol. 12, no. 2, pp. 309-320, 2016.

[3] S. Sukmawan and L. Setyowati, "Environmental Messages as Found in Indonesian Folklore and Its Relation to Foreign Language Classroom Content Analysis of the Pedagogical Content Knowledge Sukmawan \& Setyowati," Arab World English Journal (AWEJ), vol. 8, no. 1, pp. 298 308, 2017, doi: 10.24093/awej/vol8no1.21

[4] S. Safiuddin, "Wewenang Kepala Adat Dalam Pengelolaan Hutan Adat Berdasarkan Peraturan Daerah," J. Indones. Adat Law, vol. 2, no. 3, pp. $105-121,2018$

[5] S. Subarudi and I.A. Putri, "Perambahan Hutan di Taman Nasional Rawa Aopa Watumohai: sebuah Pendekatan Sosiologis," Jurnal Penelitian Sosial dan Ekonomi Kehutanan, vol. 3, no. 3, pp. 215-229, 2006.

[6] I. Owen, The Freud Wars: An Introduction to the Philosophy of Psychoanalysis, vol. 14, 2008.

[7] N.I. Sinthumule and M.L. Mashau, "Traditional ecological knowledge and practices for forest conservation in Thathe Vondo in Limpopo Province, South Africa," Glob. Ecol. Conserv., vol. 22, pp. 1-11, 2020, doi: 10.1016/j.gecco.2020.e00910.

[8] L.M.P. Ceríaco, M.P. Marques, N.C. Madeira, C.M. Vila-Viçosa, and P. Mendes, "Folklore and traditional ecological knowledge of geckos in Southern Portugal: Implications for conservation and science," J. Ethnobiol. Ethnomed., vol. 7, no. September, 2011, doi: 10.1186/17464269-7-26.

[9] E.P. Riley and N.E. Priston, "Macaques in Farms and Folklore: Exploring the Human - Nonhuman Primate Interface in Sulawesi, Indonesia," Am. J. Primatol., vol. 7, no. December 2009, pp. 1-7, 2010, doi: 10.1002/ajp.20798

[10] M.A. Preston and A.H. Harcourt, "Conservation implications of the prevalence and representation of locally extinct mammals in the folklore of Native Americans," Conserv. Soc., vol. 7, no. 1, pp. 59-69, 2009, doi: 10.4103/0972-4923.54798.

[11] E.M. Sone, "Nature in crisis: An ecological construction and conservation of the environment in Swazi oral literature," South African J. African Lang., vol. 34, no. 2, pp. 195-205, 2014, doi: 10.1080/02572117.2014.997056. 
[12] N.K. Ratna, Teori, Metode, dan Teknik Penelitian Sastra. Yogyakarta: Pustaka Pelajar, 2010.

[13] R. Barthes, Imaji, Musik, Teks: Analisis Semiologi atas Fotografi,Iklan, Film, Musik, Alkitab, Penulisan, dan Pembacaan serta Kritik Sastra. Yogyakarta: Jalasutra, 2010

[14] R.S. Limba, A. Lio, and Y.S. Husain, "Shifting Cultivation System of Indigenous Moronene as Forest Conservation on Local Wisdom Principles in Indonesia," J. Sustain. Dev., vol. 10, no. 4, pp. 121-129, 2017, doi: 10.5539/jsd.v10n4p121.
[15] R.S. Limba, B. Melamba, Z. Tahiyas, and A. Ferdinan, Sejarah Peradaban Moronene. Yogyakarta: Penerbit Lukita, 2015.

[16] H.B.P. Hastuti, H.F. Rahim, D. R. Pranawengtyas, and I. W Nitayadnya, Khazanah Sastra Daerah di Sulawesi Bagian Selatan. Kyoto: Hokuto Publishing Inc., 2016.

[17] H.B.P. Hastuti and E.W. Muis, "Syair Mo'odulele sebagai Strategi Lokal dalam Membentuk Pola Hidup Bersih dan Sehat di Tobu HukaeaLaeya (Sebuah Wacana)," in Prosiding Seminar Nasional Pemberdayaan Bahasa dan Sastra Daerah Sulawesi Tenggara dalam Membangun Karakter Masyarakat Multikultur, pp. 185-194, 2016. 